\title{
RESPONS Clitoria ternatea L. TERHADAP BERBAGAI LEVEL DOSIS DAN LAMA WAKTU INKUBASI INOKULAN RHIZOBIUM
}

\author{
Markarius Doni, I Wayan Suarna, dan N. N. Candraasih Kusumawati \\ Program Studi Sarjana Peternakan, Fakultas Universitas Udayana, Bali \\ e-mail: donimarkarius96@gmail.com
}

\begin{abstract}
ABSTRAK
Penelitian bertujuan untuk mengetahui respons Clitoria ternatea L. terhadap berbagai level dosis dan lama waktu inkubasi inokulan Rhizobium, serta untuk mengetahui interaksi antara level dosis inokulan Rhizobium dan lama inkubasi terhadap respon tanaman C. ternatea. Percobaan dilakukan di Rumah Kaca, Stasiun Penelitian Sesetan, Fakultas Peternakan, Universitas Udayana di Denpasar, Bali. Percobaan berlangsung selama 3 bulan, menggunakan rancangan acak lengkap (RAL) pola faktorial. Faktor pertama terdiri atas level dosis Rhizobium yaitu: o g kg-1 biji (Do), 7,5 $\mathrm{g} \mathrm{kg}^{-1}$ biji (D1), $15 \mathrm{~g} \mathrm{~kg}^{-1}$ biji (D2) 22,5 $\mathrm{g} \mathrm{kg}^{-1}$ biji (D3), faktor kedua terdiri atas lama waktu inkubasi yaitu: 1 jam (W1), 2 jam (W2), 3 jam (W3). Setiap perlakuan diulang sebanyak empat kali, sehingga terdapat 48 unit percobaan. Variabel yang diamati yaitu variabel pertumbuhan, variabel hasil dan variabel karakteristik. Hasil penelitian menunjukkan bahwa terjadi interaksi antara level dosis dan lama waktu inkubasi terhadap variabel bintil akar efektif. Level dosis $22,5 \mathrm{~g} \mathrm{~kg}^{-1}$ biji memberikan hasil terbaik pada variabel tinggi tanaman, jumlah daun, jumlah cabang, bintil akar efektif, berat kering daun, berat kering batang, berat kering akar, berat kering total hijauan dan luas daun. Perlakuan waktu inkubasi 3 jam memberikan hasil tertinggi pada variabel bintil akar efektif, berat kering batang dan berat kering total hijauan. Berdasarkan hasil penelitian dapat disimpulkan bahwa terjadi interaksi antara level dosis Rhizobium dan lama inkubasi terhadap variabel bintil akar efektif dan perlakuan level dosis Rhizobium 22,5 $\mathrm{g} \mathrm{kg}^{-1}$ biji dan lama waktu 3 jam memberikan pengaruh terbaik terhadap tanaman C. ternatea.
\end{abstract}

Kata kunci: Clitoria ternatea, dosis inokulan Rhizobium, waktu inkubasi

\section{Clitoria ternatea RESPONSE TO VARIOUS DOSAGE LEVELS AND RHIZOBIUM INCUBATION TIME}

\begin{abstract}
This study aims to determine the response of Clitoria ternatea L. to various dose levels and incubation time of Rhizobium inoculants, as well as to determine the interaction between Rhizobium inoculant dose levels and incubation time on the response of $C$. ternatea plants. The experiment was conducted at the Greenhouse, Sesetan Research Station, Faculty of Animal Husbandry, Udayana University on Denpasar, Bali. The experiment lasted for 3 months, using a factorial Completely Randomized Design (CRD). The first factor consists of the Rhizobium dose level, namely: $0 \mathrm{~g} \mathrm{~kg}^{-1}$ of seeds (Do), $7,5 \mathrm{~g} \mathrm{~kg}^{-1}$ of seeds (D1), $15 \mathrm{~g} \mathrm{~kg}^{-1}$ of seeds (D2), 22,5 $\mathrm{g} \mathrm{kg}^{-1}$ of seeds (D3), the second factor consisting of the length of the incubation period, namely: 1 hour (W1), 2 hours (W2), 3 hours (W3). Each treatment was repeated four times, so that there were 48 experimental units. The variables observed were growth variables, yield variables and characteristic variables. The results showed that there was an interaction between dose level and incubation time on the variable effective root nodules. The dose level of $22,5 \mathrm{~g} \mathrm{~kg}^{-1}$ of seeds gave the best results on variables of plant height, number of leaves, number of branches, effective root nodules, leaf dry weight, stem dry weight, root dry weight, total dry weight of forage and leaf area. The 3 hours incubation time treatment gave the highest results on the variable effective root nodules, stem dry weight and total dry weight of forage. Based on the results of the study, it can be concluded that there was an interaction between the Rhizobium dose level and the incubation time on the variable effective root nodules and the Rhizobium dose level treatment of $22,5 \mathrm{~g} \mathrm{~kg}^{-1}$ of seeds and the length of time of 3 hours gave the best effect on C. ternatea.
\end{abstract}

Key words: Clitoria ternatea, Rhizobium inoculant dose, incubation time. 


\section{PENDAHULUAN}

Penyediaan makanan ternak yang cukup sepanjang tahun baik kuantitas maupun kualitas merupakan salah satu upaya untuk menjaga kelangsungan produksi dan peningkatan produktivitas ternak. Permasalahan penyediaan hijauan pakan sepanjang tahun menjadi salah satu faktor vital dalam usaha peternakan, terutama pada musim kemarau. Penyediaan tanaman pakan sepanjang tahun perlu disikapi dengan berbagai inovasi secara optimal sehingga kebutuhan akan tanaman pakan dalam usaha peternakan dapat terpenuhi.

Tanaman kembang telang (Clitoria ternatea) merupakan jenis leguminosa yang berasal dari Amerika Selatan bagian Tengah yang menyebar ke daerah tropik sejak abad ke- 19, terutama Asia tenggara termasuk Indonesia. Kembang telang merupakan salah satu tanaman semak belukar yang umum tumbuh di tempat terbuka sepanjang jalan dan lereng. Tanaman ini secara alami ditemukan pada padang rumput, hutan terbuka, semak, pinggiran sungai, dan tempat-tempat terbuka lainnya, serta merupakan tanaman merambat pada tanaman pohon ataupun pagar pekarangan (Sutedi, 2013). Kembang telang beradaptasi dengan baik pada kisaran tanah berpasir, lempung, alluvial dalam, dan liat yang berat serta tahan terhadap kekeringan (curah hujan 500-900 mm), tahan terhadap salinitas dan mampu berkompetisi dengan baik terhadap gulma (Suarna, 2005).

Kembang telang adalah pakan ternak ruminansia yang mengandung nutrient yang bervariasi dan sangat baik sebagai pakan. Hijauan kembang telang mengandung protein berkisar 21-29\%, energi kasar $18,6 \mathrm{MJ} / \mathrm{Kg}$, lemak kasar 3,0\%, serat kasar 25,6\%, kecernaan bahan organik $69,7 \%$, kecernaan energi $66,6 \%$ dan energi termetabolis pada ruminan 12,4 $\mathrm{MJ} / \mathrm{kg}$ (Heuze et al., 2012). Sajimin et al. (2007) menyatakan jenis leguminosa memiliki keunggulan spesifik disamping kandungan proteinnya juga dapat tumbuh baik pada berbagai agroklimat. Kandungan protein kasar yang dimiliki leguminosa, dapat dijadikan sebagai alternatif pengganti konsentrat yang harganya relatif murah. Keunggulan lain dari daun kembang telang adalah digunakan sebagai sumber protein untuk produksi protein konsentrat daun. Keuntungan leguminosa bila dibandingkan dengan rumput adalah leguminosa dapat mengikat nitrogen atmosfer dalam simbiosisnya dengan rhizobia, kualitas hijauan leguminosa tidak menurun secara drastis sebagaimana rumput pada saat musim kemarau (Suarna et al, 2014).

Pada saat ini hasil dan kualitas hijauan pakan semakin menurun. Hal ini terjadi karena penurunan kualitas lahan (degradasi lahan) yang disebabkan oleh penggunaan pupuk kimia secara terusmenerus dalam jumlah yang banyak serta adanya pengurasan sumber daya lahan tanpa diimbangi dengan rehabilitasi lahan (Kartini, 2000). Selanjutnya Supadma (2006) menyatakan bahwa sejak tahun 1984 pemakaian pupuk buatan oleh petani di Indonesia yang semakin meningkat dapat memaksimalkan hasil pertanian secara nyata dan cepat, namun kualitas lahan menurun. Hal ini menyadarkan masyarakat akan pentingnya sistem pertanian ramah lingkungan dan pemanfaatan bakteri untuk memfiksasi $\mathrm{N}$ dari udara bebas.

Bakteri Rhizobium adalah sekelompok bakteri yang bersimbiosis dengan tanaman leguminosa dan hanya dapat memfiksasi nitrogen atmosfer bila berada di dalam bintil akar tanaman leguminosa. Peran Rhizobium terhadap pertumbuhan tanaman berkaitan dengan ketersediaan hara bagi tanaman inangnya. Simbiosis ini menyebabkan bakteri Rhizobium dapat menambat nitrogen dari atmosfir, dan selanjutnya digunakan oleh tanaman inangnya (Sari, 2010).

Salah satu usaha meningkatkan penambatan nitrogen adalah inokulasi menggunakan strain Rhizobium yang sesuai dan efektif. Penelitian yang dilakukan oleh Purwantari dan Sajimin (2017) menyatakan bahwa produksi hijauan pada tanaman Indigofera zollingeriana yang diinokulasi dengan strain Rhizobium IG menunjukkan adanya peningkatan secara nyata. Dalam penelitian yang dilakukan oleh Rizqiani et al. (2007) menunjukkan pemberian pupuk cair dengan dosis 0,0625 $\mathrm{ml}$ bakteri Rhizobium untuk setiap $25 \mathrm{~cm}^{2}$, dapat meningkatkan pertumbuhan dan produksi tanaman Phaseolus vulgaris. Hasil penelitian Suarna et al. (2016) menunjukkan bahwa pemberian pupuk organik akan mampu menyediakan kondisi yang sangat cocok bagi perkembangan mikrobia di dalam tanah sehingga asosiasi antara rumput dengan legume dapat meningkatkan produksi hijauan. Hasil penelitian sebelumnya yang dilakukan oleh Umami et al. (2014) mendapatkan bahwa penambahan inokulan Rhizobium menyebabkan pertumbuhan diameter batang, berat kering tanaman bagian bawah, SK, PK, dan BETN jerami, produksi BK dan produksi BO jerami kedelai edamame lebih baik daripada tanpa penambahan inokulan.

Berdasarkan uraian diatas maka, peneliti tertarik untuk mengamati respon Clitoria ternatea terhadap berbagai level dosis dan lama waktu inkubasi inokulan Rhizobium.

\section{MATERI DAN METODE}

Percobaan dilaksanakan di Rumah Kaca, Stasiun Penelitian Sesetan, Fakultas Peternakan, Universitas Udayana. Bibit yang digunakan adalah biji kembang 
telang lokal (Clitoria ternatea L.) yang diperoleh dari Laboratorium Ilmu Tumbuhan Pakan Universitas Udayana. Tanah yang digunakan dalam penelitian ini berasal dari Stasiun Penelitian Fakultas Peternakan Universitas Udayana di Desa Pengotan, Kabupaten Bangli, yang memiliki tekstur pasir berlempung dengan kandungan $\mathrm{C}$ organik 1,22\% (rendah), $\mathrm{N}$ total o,13\% (rendah), P tersedia 45,43 ppm (sangat tinggi), kadar air kering udara $(\mathrm{Ku})$ 4,07\% dan kapasitas lapang 30,52\%. Tanah yang akan dipakai terlebih dahulu dikering udarakan, kemudian ditumbuk halus, selanjutnya diayak dengan tujuan agar ukuran partikel tanah merata. Tanah ditimbang dan dimasukkan ke dalam pot yang masing-masing diisi sebanyak $4 \mathrm{~kg}$ tanah kering udara. Tanah dalam pot kemudian disiram dengan air sampai kapasitas lapang.

Percobaan menggunakan pot berbahan dasar plastik yang berdiameter $26 \mathrm{~cm}$ dan tinggi $19 \mathrm{~cm}$ sebanyak 48 buah. Rhizobium yang digunakan adalah inokulasi Rhizobium yang diperoleh dari Laboratorium Mikrobiologi, Fakultas Pertanian UGM Jogjakarta, parameternya adalah Legin LCC berisi 1.000 gram, mengandung Rhizobium spp. 10.000.000 - 1.000.000.000 sel tiap gram.

Percobaan ini menggunakan rancangan acak lengkap (RAL) pola faktorial dengan dua faktor. Faktor pertama adalah level dosis yaitu: Do: tanpa pemberian inokulan Rhizobium, D1: pemberian inokulan Rhizobium dosis 7,5 $\mathrm{g} \mathrm{kg}^{-1}$ biji, D2: pemberian inokulan Rhizobium dosis $15 \mathrm{~g} \mathrm{~kg}^{-1}$ biji, D3: pemberian inokulan Rhizobium dosis $22,5 \mathrm{~g} \mathrm{~kg}^{-1}$ biji. Faktor kedua adalah Waktu inkubasi, yaitu: W1: waktu inkubasi 1 jam, W2: waktu inkubasi 2 jam dan W3: waktu inkubasi 3 jam. Perlakuan ini diulang sebanyak 4 kali sehingga terdapat 48 unit percobaan.

Variabel yang diamati dalam penelitian ini adalah: tinggi tanaman, jumlah daun, jumlah cabang, bintil akar efektif, berat kering daun, berat kering batang, berat kering akar, berat kering total hijauan, nisbah berat kering daun dengan berat kering batang, nisbah berat kering total hijauan dengan berat kering akar, dan luas daun per pot $\left(\mathrm{cm}^{2}\right.$ pot $\left.^{-1}\right)$.

\section{HASIL DAN PEMBAHASAN}

Hasil penelitian Clitoria ternatea menunjukkan bahwa terjadi interaksi antara level dosis dan lama waktu inkubasi inokulan Rhizobium pada variabel bintil akar efektif Clitoria ternatea. Interaksi antara perlakuan dosis dan waktu berpengaruh nyata terhadap variabel bintil akar efektif (Tabel 1) sedangkan terhadap variabel yang lainnya memberikan hasil yang sama. Keadaan tersebut menunjukkan bahwa pemberian inokulan Rhizobium dosis 22,5 g $\mathrm{kg}^{-1}$ biji dan waktu inkubasi 3 jam mampu secara efektif bersimbiosis dengan Clitoria ternatea sehingga meningkatkan jumlah bintil akar. Menurut Gomez dan Gomez (1995) bahwa dua faktor perlakuan dikatakan berinteraksi apabila pengaruh suatu faktor perlakuan berubah pada saat perubahan taraf faktor perlakuan lainnya. Interaksi terjadi pada level dosis dan lama inkubasi terlama. Interaksi diperoleh pada level dosis tertinggi dan waktu inkubasi terlama, fenomena ini mengisyaratkan bahwa level dosis tertinggi dan waktu inkubasi terlama masih bisa ditingkatkan lagi sehingga akan dapat diperoleh dosis dan waktu inkubasi yang optimal.

Perlakuan lama waktu inkubasi 3 jam pada tanaman Clitoria ternatea memberikan hasil tertinggi namun tidak memberikan pengaruh nyata $(\mathrm{P}>0,05)$ pada variabel pertumbuhan tinggi tanaman, jumlah daun dan jumlah cabang. Hal ini diduga karena lama waktu yang dibutuhkan untuk menginkubasi relatif pendek sehingga kemungkinan pengaruhnya belum optimal, karena respon dari Rhizobium untuk bersimbiosis dengan akar tanaman Clitoria ternatea tergolong lambat. Nasikah (2007), menyatakan bahwa nitrogen di atmosfer dapat berupa urea $\mathrm{CO}\left(\mathrm{NH}_{2}\right)_{2}, \mathrm{~N}_{2}$ dan $\mathrm{N}$. Akan tetapi tidak ada yang secara langsung dapat digunakan oleh tanaman. Nitrogen memasuki tanah dalam bentuk ammonia dan nitrat $\left(\mathrm{NH}_{3}\right)$ bersama air dalam bentuk penambatan $\mathrm{N}_{2}$ oleh mikroba atau dalam bentuk penambahan pupuk sintesis. Nitrogen yang terbentuk kemudian diubah menjadi ammonia melalui proses deaminasi karena ammonia dapat secara langsung diasimilasikan oleh mikroba atau diubah terlebih dahulu menjadi senyawa nitrat secara nitrifikasi. Perlakuan lama waktu inkubasi 3 jam memberikan hasil rataaan tertinggi dan berbeda nyata pada variabel bintil akar efektif yaitu sebesar 54,4 bintil efektif. Hal ini membuktikan bahwa lama waktu inkubasi menentukan populasi Rhizobium sehingga mempengaruhi jumlah nodul yang efektif. Populasi Rhizobium yang rendah menyebabkan rendahnya peluang Rhizobium dalam menginfeksi akar tanaman legum (Gradner et al., 1991).

Pemberian dosis inokulan 22,5 $\mathrm{g} \mathrm{kg}^{-1}$ biji tertinggi pada variabel tinggi tanaman, jumlah daun, jumlah cabang dan bintil akar efektif yaitu sebesar 271,83, 45,50, 8,25, dan 60,8 (Tabel ${ }_{1}$ ). Hal tersebut disebabkan karena unsur hara nitrogen yang dibutuhkan oleh tanaman pada pemberian level dosis inokulan 22,5 $\mathrm{g} \mathrm{kg}^{-1}$ biji lebih cepat tersedia sehingga tanaman Clitoria ternatea dapat tumbuh dengan baik, sehingga berpengaruh positif terhadap variabel pertumbuhan tinggi tanaman, jumlah daun, jumlah cabang dan bintil akar efektif. Bakteri Rhizobium merupakan mikroba tanah yamg mampu mengikat nitrogen bebas di udara menjadi ammonia $\left(\mathrm{NH}_{3}\right)$ yang akan diubah menjadi asam amino yang selanjutnya 
Tabel 1. Respons Pertumbuhan Clitoria ternatea terhadap Berbagai Level Dosis dan Lama Waktu Inkubasi Inokulan Rhizobium

\begin{tabular}{|c|c|c|c|c|c|c|c|}
\hline \multirow{2}{*}{ Variabel } & \multirow{2}{*}{ Waktu Inkubasi ${ }^{1)}$} & \multicolumn{4}{|c|}{ Dosis $^{2)}$} & \multirow{2}{*}{ Rataan } & \multirow{2}{*}{$\mathrm{SEM}^{3}$} \\
\hline & & Do & D1 & D2 & D3 & & \\
\hline \multirow[t]{4}{*}{ Tinggi tanaman $(\mathrm{cm})$} & W1 & 262,25 & 261,00 & 260,00 & 261,25 & $261,13^{\mathrm{a}}$ & 7,17 \\
\hline & $\mathrm{W} 2$ & 252,50 & 253,25 & 257,75 & 264,00 & $256,88^{a}$ & \\
\hline & $\mathrm{W}_{3}$ & 246,00 & 251,50 & 262,50 & 290,25 & $262,5^{6^{a}}$ & \\
\hline & Rataan & $253,5^{\left.8^{\mathrm{B}} 4\right)}$ & $255,25^{\mathrm{B}}$ & $260,08^{\mathrm{AB}}$ & $271,83^{\mathrm{A}}$ & & \\
\hline \multirow[t]{4}{*}{ Jumlah daun (helai) } & $\mathrm{W} 1$ & 33,50 & 34,25 & 38,00 & 42,75 & $37,13^{\mathrm{a}}$ & 5,27 \\
\hline & $\mathrm{W} 2$ & 37,75 & 32,00 & 41,50 & 40,50 & $37,94^{\mathrm{a}}$ & \\
\hline & $\mathrm{W}_{3}$ & 35,00 & 31,50 & 34,75 & 53,25 & $38,63^{\mathrm{a}}$ & \\
\hline & Rataan & $35,42^{\mathrm{B}}$ & $32,5^{8^{B}}$ & $38,08^{\mathrm{AB}}$ & $45,5 \mathrm{O}^{\mathrm{A}}$ & & \\
\hline \multirow[t]{4}{*}{ Jumlah cabang (batang) } & W1 & 6,00 & 6,25 & 6,75 & 8,00 & $6,75^{\mathrm{a}}$ & 0,99 \\
\hline & $\mathrm{W} 2$ & 6,75 & 6,25 & 6,50 & 7,25 & $6,69^{\mathrm{a}}$ & \\
\hline & $\mathrm{W}_{3}$ & 5,50 & 5,75 & 7,25 & 9,50 & $7,00^{\mathrm{a}}$ & \\
\hline & Rataan & $6,08^{\mathrm{B}}$ & $6,08^{B}$ & $6,83^{\mathrm{AB}}$ & $8,25^{\mathrm{A}}$ & & \\
\hline \multirow[t]{4}{*}{ Bintil akar efektif (\%) } & W1 & $\begin{array}{c}37,5^{\mathrm{B}} \\
\mathrm{a}\end{array}$ & $\begin{array}{c}37,5^{\mathrm{B}} \\
\mathrm{a}\end{array}$ & $\begin{array}{c}60,0^{A} \\
a\end{array}$ & $\begin{array}{c}42,5^{\mathrm{AB}} \\
\mathrm{b}\end{array}$ & $\begin{array}{c}44,4 \\
b\end{array}$ & 0,61 \\
\hline & W2 & $\begin{array}{c}47,5^{\mathrm{B}} \\
\mathrm{a}\end{array}$ & $\begin{array}{c}55, \mathrm{O}^{\mathrm{AB}} \\
\mathrm{a}\end{array}$ & $\begin{array}{c}45,0^{B} \\
a\end{array}$ & $\begin{array}{c}67,5^{\mathrm{A}} \\
\mathrm{a}\end{array}$ & $\begin{array}{c}53,8 \\
\text { a }\end{array}$ & \\
\hline & $\mathrm{W}_{3}$ & $\begin{array}{c}32,5^{\mathrm{C}} \\
\mathrm{a}\end{array}$ & $\begin{array}{c}52,5^{\mathrm{B}} \\
\mathrm{a}\end{array}$ & $\begin{array}{c}60,0^{\mathrm{AB}} \\
\mathrm{a}\end{array}$ & $\begin{array}{c}72,5^{\mathrm{A}} \\
\mathrm{a}\end{array}$ & $\begin{array}{c}54,4 \\
\mathrm{a}\end{array}$ & \\
\hline & Rataan & $39,2^{\mathrm{C}}$ & $48,3^{\mathrm{BC}}$ & $55, \mathrm{O}^{\mathrm{AB}}$ & $60,8^{A}$ & & \\
\hline
\end{tabular}

Keterangan:

1) $W 1=$ waktu 1 jam, W2 = waktu 2 jam, W3 = waktu 3 jam

2) $\mathrm{D0}=0 \mathrm{~g}$ kg-1 biji, $\mathrm{D} 1=7,5 \mathrm{~g} \mathrm{~kg}-1 \mathrm{biji}, \mathrm{D} 2=15 \mathrm{~g} \mathrm{~kg}-1 \mathrm{biji}, \mathrm{D} 3=22,5 \mathrm{~g} \mathrm{~kg}-1$ biji

3) SEM = Standard Error of the Treatment Means

4) Nilai dengan huruf kapital berbeda pada baris yang sama dan huruf kecil yang berbeda pada kolom yang sama menunjukkan berbeda nyata $(P<0,05)$

menjadi senyawa nitrogen yang diperlukan tanaman untuk tumbuh dan berkembang. Bila unsur $\mathrm{N}$ tersedia bagi tanaman maka kandungan klorofil pada daun akan meningkat dan proses fotosintesis juga meningkat sehingga asimilat yang dihasilkan lebih banyak, akibatnya pertumbuhan tanaman lebih baik (Adnyana, 2012). Hal ini sejalan dengan pendapat Agustina (1990) dan Jumin (2005), bahwa ketersediaan unsur hara dalam jumlah yang cukup dan seimbang merupakan faktor utama yang sangat menentukan tingkat keberhasilan pertumbuhan dan produksi tanaman yang maksimum.

Perlakuan lama waktu inkubasi 3 jam memberikan memberikan hasil rataan tertinggi namun tidak memberikan pengaruh nyata $(\mathrm{P}>0,05)$ pada variabel berat kering daun dan berat kering akar tanaman Clitoria ternatea yaitu sebesar 2,26 g, dan 0,91 g (Tabel 2). Hal ini terjadi karena proses simbiosis antara akar tanaman dan Rhizobium membutuhkan beberapa tahapan. Nasikah (2007), menyatakan bahwa nitrogen di atmosfer dapat berupa urea $\mathrm{CO}\left(\mathrm{NH}_{2}\right)_{2}, \mathrm{~N}_{2}$ dan N. Akan tetapi tidak ada yang secara langsung dapat digunakan oleh tanaman. Nitrogen memasuki tanah dalam bentuk ammonia dan nitrat $\left(\mathrm{NH}_{3}\right)$ bersama air dalam bentuk penambatan $\mathrm{N}_{2}$ oleh mikroba atau dalam bentuk penambahan pupuk sintesis. Nitrogen yang terbentuk kemudian diubah menjadi ammonia melalui proses deaminasi karena ammonia dapat secara langsung diasimilasikan oleh mikroba atau diubah terlebih dahulu menjadi senyawa nitrat secara nitrifikasi.

Perlakuan lama waktu inkubasi 3 jam pada tanaman Clitoria ternatea memberikan perbedaan hasil yang nyata pada variabel berat kering batang dan berat kering total hijauan. Hal ini terjadi karena Rhizobium mampu bersimbiosis dengan bintil akar tanaman Clitoria ternatea sehingga menghasilkan unsur hara, selanjutnya tanaman menyerap unsur hara tersebut untuk meningkatkan pertumbuhan dan hasil tanaman. Semakin tinggi ketersediaan unsur hara maka tanaman mampu menyerap unsur hara untuk pertumbuhan dan perkembangan tanaman (Agusman 2004). Suastika (2012) menyatakan bahwa semakin tinggi tanaman dan banyak jumlah cabang, semakin banyak daun dan semakin lebar luas daun menyebabkan tanaman lebih banyak menyerap unsur hara dan sinar matahari sehingga proses fotosintesis akan berjalan lebih baik. Hal tersebut akan menyebabkan karbohidrat dan protein yang dihasilkan akan lebih banyak dan akan disebarkan keseluruh bagian tanaman sehingga berat kering tanaman meningkat.

Hasil penelitian Clitoria ternatea pada perlakuan pemberian dosis inokulan 22,5 $\mathrm{g} \mathrm{kg}^{-1}$ biji menunjukkan bahwa terdapat perbedaan yang nyata pada variabel berat kering daun, berat kering batang, berat kering akar, dan berat kering total hijauan. Hal ini karena didukung dengan rata-rata tertinggi pada variabel tinggi tanaman, jumlah daun, jumlah cabang dan bintil akar efektif. Pendapat ini didukung oleh 
Tabel 2. Respons Clitoria ternatea terhadap Berbagai Level Dosis dan Lama Waktu Inkubasi Inokulan Rhizobium

\begin{tabular}{|c|c|c|c|c|c|c|c|}
\hline \multirow{2}{*}{ Variabel } & \multirow{2}{*}{$\begin{array}{c}\text { Waktu } \\
\text { Inkubasi }^{11}\end{array}$} & \multicolumn{4}{|c|}{$\operatorname{Dosis}^{2)}$} & \multirow{2}{*}{ Rataan } & \multirow{2}{*}{ SEM $^{3)}$} \\
\hline & & Do & D1 & D2 & D3 & & \\
\hline \multirow[t]{4}{*}{ Berat kering daun (g) } & W1 & 1,65 & 1,90 & 1,78 & 2,48 & $1,95^{\mathrm{a}}$ & 0,27 \\
\hline & W2 & 1,85 & 1,78 & 2,10 & 2,50 & $2,06^{\mathrm{a}}$ & \\
\hline & $\mathrm{W}_{3}$ & 1,63 & 1,73 & 2,40 & 3,30 & $2,26^{\mathrm{a}}$ & \\
\hline & Rataan & $\left.1,71^{B} 4\right)$ & $1,80^{B}$ & $2,09^{\mathrm{B}}$ & $2,76^{\mathrm{A}}$ & & \\
\hline \multirow[t]{4}{*}{ Berat kering batang (g) } & W1 & 1,55 & 1,63 & 1,53 & 2,23 & $1,73^{\mathrm{b}}$ & 0,26 \\
\hline & W2 & 1,60 & 1,45 & 2,05 & 2,23 & $1,83^{b}$ & \\
\hline & $\mathrm{W}_{3}$ & 1,88 & 1,63 & 2,35 & 3,03 & $2,22^{\mathrm{a}}$ & \\
\hline & Rataan & $1,68^{\mathrm{B}}$ & $1,57^{\mathrm{B}}$ & $1,98^{\mathrm{B}}$ & $2,49^{\mathrm{A}}$ & & \\
\hline \multirow[t]{4}{*}{ Berat kering akar (g) } & $\mathrm{W} 1$ & 0,73 & 0,68 & 0,73 & 1,05 & $0,79^{\mathrm{a}}$ & 0,16 \\
\hline & W2 & 0,63 & 0,63 & 0,98 & 1,05 & $0,82^{\mathrm{a}}$ & \\
\hline & W3 & 0,63 & 0,78 & 0,95 & 1,30 & $0,91^{\mathrm{a}}$ & \\
\hline & Rataan & $0,66^{\mathrm{B}}$ & $0,69^{B}$ & $0,88^{\mathrm{AB}}$ & $1,13^{\mathrm{A}}$ & & \\
\hline \multirow[t]{4}{*}{ Berat kering total hijauan (g) } & W1 & 3,20 & 3,53 & 3,30 & 4,70 & $3,68^{\mathrm{b}}$ & 0,51 \\
\hline & W2 & 3,45 & 3,23 & 4,15 & 4,73 & $3,89^{\mathrm{ab}}$ & \\
\hline & W3 & 3,50 & 3,35 & 4,75 & 6,33 & $4,48^{\mathrm{a}}$ & \\
\hline & Rataan & $3,38^{\mathrm{B}}$ & $3,37^{\mathrm{B}}$ & $4,07^{\mathrm{B}}$ & $5,25^{\mathrm{A}}$ & & \\
\hline
\end{tabular}

Keterangan:

1) W1 = waktu 1 jam, W2 = waktu 2 jam, W3 = waktu 3 jam

2) $\mathrm{DO}=0 \mathrm{~g} \mathrm{~kg}^{-1}$ biji, D1 $=7,5 \mathrm{~g} \mathrm{~kg}^{-1}$ biji, D2 $=15 \mathrm{~g} \mathrm{~kg}^{-1} \mathrm{biji}, \mathrm{D} 3=22,5 \mathrm{~g} \mathrm{~kg}^{-1} \mathrm{biji}$

3) $\mathrm{SEM}=$ Standard Error of the Treatment Means

4) Nilai dengan huruf kapital berbeda pada baris yang sama dan huruf kecil yang berbeda pada kolom yang sama menunjukkan berbeda nyata $(P<0,05)$

Tabel 3. Respons karakteristik Clitoria ternatea terhadap Berbagai Level Dosis dan Lama Waktu Inkubasi Inokulan Rhizobium

\begin{tabular}{|c|c|c|c|c|c|c|c|}
\hline \multirow{2}{*}{ Variabel } & \multirow{2}{*}{$\begin{array}{c}\text { Waktu } \\
\text { Inkubasi }^{1)}\end{array}$} & \multicolumn{4}{|c|}{ Dosis $^{2)}$} & \multirow{2}{*}{ Rataan } & \multirow{2}{*}{ SEM 3 ） } \\
\hline & & Do & D1 & D2 & D3 & & \\
\hline \multirow{4}{*}{$\begin{array}{l}\text { Nisbah Berat Kering Daun } \\
\text { dengan Berat Kering Batang }\end{array}$} & $\mathrm{W} 1$ & 1,08 & 1,26 & 1,17 & 1,11 & $1,15^{\mathrm{a}}$ & \multirow{4}{*}{0,09} \\
\hline & $\mathrm{W} 2$ & 1,16 & 1,24 & 1,04 & 1,13 & $1,14^{\mathrm{a}}$ & \\
\hline & $\mathrm{W}_{3}$ & 0,87 & 1,05 & 1,07 & 1,09 & $1,02^{\mathrm{a}}$ & \\
\hline & Rataan & $1,03^{\mathrm{A} 4)}$ & $1,19^{\mathrm{A}}$ & $1,09^{\mathrm{A}}$ & $1,11^{\mathrm{A}}$ & & \\
\hline \multirow{4}{*}{$\begin{array}{l}\text { Nisbah Berat Kering Total Hi- } \\
\text { jauan dengan Berat Kering Akar }\end{array}$} & W1 & 4,50 & 5,31 & 4,76 & 4,61 & $4,79^{\mathrm{a}}$ & \multirow{4}{*}{0,62} \\
\hline & $\mathrm{W} 2$ & 5,81 & 5,43 & 4,27 & 4,72 & $5,06^{\mathrm{a}}$ & \\
\hline & $\mathrm{W}_{3}$ & 6,56 & 4,45 & 5,68 & 5,04 & $5,43^{\mathrm{a}}$ & \\
\hline & Rataan & $5,62^{\mathrm{A}}$ & $5,07^{\mathrm{A}}$ & $4,90^{\mathrm{A}}$ & $4,79^{\mathrm{A}}$ & & \\
\hline \multirow[t]{4}{*}{ Luas Daun per Pot $\left(\mathrm{cm}^{2} \mathrm{pot}^{-1}\right)$} & $\mathrm{W} 1$ & $9645 \cdot 76$ & $10315 \cdot 32$ & $12315 \cdot 74$ & 15527.99 & $11951.20^{\mathrm{a}}$ & \multirow{4}{*}{3788,87} \\
\hline & $\mathrm{W} 2$ & 14190.68 & $7164 \cdot 78$ & $14194 \cdot 33$ & 19021.63 & $13642.86^{\mathrm{a}}$ & \\
\hline & W3 & 10541.64 & 10829.57 & 18700.23 & 18882.23 & $14738.42^{\mathrm{a}}$ & \\
\hline & Rataan & $11459.3^{\mathrm{B}}$ & $9436.55^{\mathrm{B}}$ & $15070.10^{\mathrm{AB}}$ & $17810.61^{\mathrm{A}}$ & & \\
\hline
\end{tabular}

Keterangan:

1) $\mathrm{W} 1=$ waktu 1 jam, $\mathrm{W} 2$ = waktu 2 jam, $\mathrm{W} 3=$ waktu 3 jam

2) $\mathrm{D} 0=0 \mathrm{~g} \mathrm{~kg}^{-1}$ biji, D1 $=7,5 \mathrm{~g} \mathrm{~kg}^{-1}$ biji, D2 $=15 \mathrm{~g} \mathrm{~kg}^{-1}$ biji, D3 $=22,5 \mathrm{~g} \mathrm{~kg}^{-1} \mathrm{biji}$

3) $\mathrm{SEM}=$ Standard Error of the Treatment Means

4) Nilai dengan huruf kapital berbeda pada baris yang sama dan huruf kecil yang berbeda pada kolom yang sama menunjukkan berbeda nyata $(P<0,05)$

Zuchri (2006), yang menyatakan bahwa semakin baik pertumbuhan tanaman dan semakin banyak unsur hara serta air yang terserap maka bobot kering tanaman semakin berat. Pada level dosis inokulan Rhizobium 22,5 $\mathrm{g} \mathrm{kg}^{-1}$ biji, unsur hara nitrogen yang dibutuhkan tanaman dapat terpenuhi sehingga tanaman Clitoria ternatea akan dapat berproduksi dengan optimal. Rhizobium mampu bersimbiosis dengan bintil akar tanaman Clitoria ternatea sehingga menghasilkan unsur hara nitrogen, selanjutnya tanaman menyerap unsur hara tersebut untuk meningkatkan pertumbuhan dan hasil tanaman. Hakim et al. (1986) menyatakan bahwa produksi hijauan pakan dapat dicapai seoptimal mungkin jika macam dan jumlah hara yang ditambahkan dalam jumlah yang cukup dan seimbang dengan kebutuhan tanaman.

Nisbah berat kering daun dengan berat kering batang Clitoria ternatea menunjukkan pengaruh tidak nyata. Daun merupakan tempat terjadinya fotosintesis dan respirasi sehingga daun lebih banyak mengandung protein dan lemak dibanding batang, yang secara tidak langsung mencerminkan kualitas hijauan. Daun lebih banyak mengandung protein dibangding batang sehingga dengan semakin berkurangnya perbandingan daun dan batang akan 
menyebabkan turunnya kadar protein hijauan (Tillman et al., 1991).

Nisbah berat kering daun dengan berat kering batang dan nisbah berat kering total hijauan dengan berat kering akar tanaman Clitoria ternatea pada dosis $22,5 \mathrm{~g} \mathrm{~kg}^{-1}$ biji menunjukkan perbedaan yang tidak nyata dan memberikan rataan yang rendah. Daun lebih banyak mengandung protein dibanding batang sehingga dengan semakin berkurangnya perbandingan daun dan batang akan menyebabkan turunnya kadar protein hijauan (Tillman et al., 1991).

Luas daun Clitoria ternatea pada perlakuan dosis $22,5 \mathrm{~g} \mathrm{~kg}^{-1}$ biji menunjukkan perbedaan yang nyata. Hal ini didukung dari perlakuan D3 yang menghasilkan luas daun paling tinggi. Pemberian inokulan Rhizobium dengan dosis 22,5 $\mathrm{g} \mathrm{kg}^{-1}$ biji mampu memacu pertumbuhan bintil akar tanaman Clitoria ternatea sehingga tanaman mampu memfiksasi unsur $\mathrm{N}$ lebih baik sehingga pertumbuhan daun lebih baik. Kartasapoetra dan Sutedjo (2002) menyatakan bahwa fungsi $\mathrm{N}$ antara lain untuk menigkatkan pertumbuhan daun. Daun tanaman akan menjadi banyak dan lebar serta warna yang lebih hijau.

\section{SIMPULAN}

Berdasarkan hasil penelitian ini dapat disimpulkan bahwa pemberian dosis inokulan yang semakin tinggi dan waktu inkubasi yang semakin lama dapat meningkatkan respons pertumbuhan, hasil, dan karakteristik Clitoria ternatea. Terjadi interaksi antara dosis inokulan Rhizobium dan lama waktu inkubasi pada variabel bintil akar efektif tanaman Clitoria ternatea.

\section{DAFTAR PUSTAKA}

Adnyana, G. M. 2012. Mekanisme Penambatan Nitrogen Udara oleh Bakteri Rhizobium Menginspirasi Perkembangan Teknologi Pemupukan Organik yang Ramah Lingkungan. Agrotop, 2(2) : 145-149.

Gomez, K. A., dan A. A. Gomez. 1995. Prosedur Statistik untuk Pertanian. Edisi Ke-2. Universitas Indonesia. Jakarta.

Heuze, V., G. Tran., D. Bastianelli., M. Boval., F. Lebas. 2012. Butterfly Pea (Clitoria ternatea). Feedipedia.org. A programme by INRA CIRAD, $A F Z$, and FAO. http://www.feedipedia.org/ node/318 Last update on May 24, 2012, 1:13.

Kartini 2000. Pertanian Organik Sebagai Pertanian Masa Depan. Prosiding Seminar Nasional Pengembangan Teknologi Pertanian dalam Upaya Mendukung Ketahanan Pangan Nasional. Pusat Penelitian dan Pengembangan Sosial Ekonomi
Pertanian bekerjasama dengan Universitas Udayana Denpasar.

Nasikah. 2007. Pengaruh Inokulasi Rhizobium dan Waktu Pemberian Pupuk N (Urea) terhadap Pertumbuhan dan Hasil Kedelai di Lahan Sawah setelah Kedelai (Glycine max L. Merrill). Skripsi pada Jurusan Biologi. Fakultas Sains dan Teknologi. Universitas Islam Negeri Malang. Malang.

Purwantari, N. D dan Sajimin. 2017. Respon Indigofera zollingeriana terhadap inokulasi strain Rhizobium. Jurnal Pastura Himpunan Ilmuwan Tumbuhan Pakan Indonesia. https:// ojs.unud.ac.id/index.php/pastura/article/ view $/ 32718$

Rizqiani, N. F., E. Ambarwati dan N. W. Yuwono. 2007. Pengaruh dosis dan frekuensi pemberian pupuk organik cair terhadap pertumbuhan dan hasil buncis (Phaseolus vulgaris L.) dataran rendah. Jurnal Ilmu Tanah dan Lingkungan, 7 (1): 43-53. Sajimin, I. Hendrawan dan B. R. Prawiradiputra. 2007. Produksi tiga jenis hijauan leguminosa herba dan palatabilitasnya pada ternak domba. Seminar Nasional Teknologi Peternakan dan Veteriner.

Sari, P. 2010. Efektivitas Beberapa Formula Pupuk Hayati Rhizobium Toleran Masam pada Tanaman Kedelai di Tanah Masam Ultisol. Skripsi. Fakultas Sains dan Teknologi Universitas Islam Negeri (UIN) Maulana Malik Ibrahim Malang. 107 hal.

Suarna, I. W. 2005. Kembang Telang (Clioria ternatea) Tanaman Pakan dan Penutup Tanah. Prosiding Lokakarya Nasional Tanaman Pakan Ternak. Puslitbang Peternakan.

Suarna, I. W., N. N. C. Kusumawati., dan M. A. P. Duarsa. 2014. Model Asosiasi Tanaman Pakan Adaptif untuk Perbaikan Lahan Pasca Tambang di Kabupaten Karangasem. Jurnal Bumi Lestari, 14 (1): 9-14.

Suarna, I. W. dan I. K. M. Budiasa. 2016. Pengaruh pupuk organic terhadap produksi dan kualitas hijauan pasture campuran pada lahan kering di desa Sebudi Karangasem. Majalah Ilmiah Peternakan, Vol. 19 No. 3: 125-128.

Sutedi, E. 2013. Potensi kembang telang (Clitoria ternatea) sebagai tanaman pakan ternak. Buletin Ilmu Peternakan dan Kesehatan Hewan Indonesia. Volume : 23 Nomor : 2.

Umami, N., H. M. Wijayanti., D. A. M. Nurdani., R. Utomo., R. D. Soetrisno., B. Suhartanto., B. Suwignyo, dan C. Wulandari. 2014. Penambahan inokulum dalam meningkatkan kualitas jerami kedelai edamame (Glycine max var Ryokhoho) sebagai pakan ternak. Jurnal Pastura. https:// ojs.unud.ac.id/index.php/pastura/article/ view/9012 